\title{
Calvin's exposition of the sixth commandment as a trajectory in his catechetical works
}

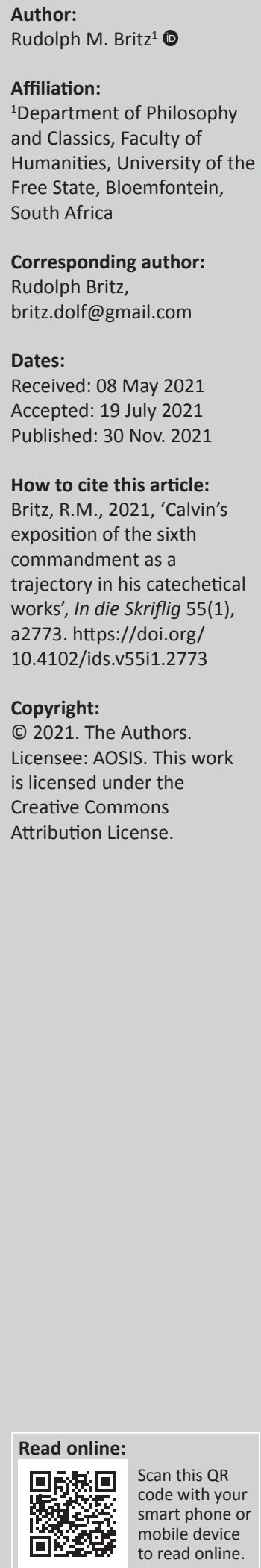

In this article is explored the key theological and pedagogical trajectories which shaped Calvin's teaching of the sixth commandment ('You shall not kill') in his catechetical publications. These include the Instruction of 1537/1538, l'Institution Puerile de la Doctrine Chrestienne (15381541), the 1542 and 1545 Catechismus, and La Maniere d'Interroguer les Enfans (1551). The overall objective is not only to depict the theological line of argumentation as a development, but also to map out Calvin's pedagogy and teaching strategies. In Calvin research, this aspect of his teaching is undervalued. This was in particular illustrated by studying the relevant source texts in chronological order. The method employed in which the original texts were read, explicated and compared to contemporary texts (Luther, Jud and Bucer), confirmed that Calvin's basic argument should indeed by explicated contextually, based on the original language of publication. This approach also provided the opportunity to identify patterns in Calvin's exposition that normally remain beyond the interests of investigators. One of these was the underpinning pedagogy. The results indicated that Calvin's teaching of the commandment was ingrained in the understanding and enduring meaning of the Law for the Christian church given in the words of Christ in Matthew 5:21, 22 and 22:39. The practical implications of the Command should not be attributed to the particular use of the Law as a rule of life in the born-again. Calvin's underpinning pedagogy allowed not only for an envisioned transfer of knowledge, but also for the unpacking of that knowledge content in terms of practical competencies and skills to live a spontaneous Christian life. In this sense, a dynamic educational strategy guided the learner by challenging questions to consider and think, and then to respond independently.

Contribution: This article employed a significant historical-chronological method for studying pre-1551 Calvin texts. An appraisal of the contextual development of his thinking on 'You shall not kill' was argued within the framework of teaching and learning. It also created the opportunity to ask new questions to the texts such as the pedagogy that underpinned the catechetical work of Calvin.

Keywords: Calvin; catechetical instruction; Genevan catechetical footprint; Calvin's pedagogy; Catechesis during the Reformation; Calvin on the sixth commandment; Calvin's teaching and learning strategies; Decalogue.

\section{Introduction}

In recent scholarship, the teaching of children in Calvin's theology has often been the subject of discussion (Britz \& d'Assonville 2010; Hesselink 1997; Kloosterman-Van der Sluys 2009:150-167; Kingdon 2004:294-313; Pitkin 2001; Zachman 2006:131-146). Calvin's catechetical publications are considered to be tangible evidence of the conspicuous prominence he attributed to their instruction. This education is carried by a theology, Selderhuis (2010:128) states, in which humankind's total corruption is undeniably taught; however, in which the grace of God can nevertheless equivocally transform people and that God's Spirit can prompt them to great deeds of sanctification and rejuvenation. ${ }^{1}$ In this education, the exposition of the Decalogue played a pivotal role.

Two years earlier, Freudenberg (2008:204-212), in his exposition of the Calvin's 'Katechismen', utilised the same line of argumentation. He noted that Calvin's enunciation of good works in the Genevan Catechism (1545, questions 116-130) finds expression in the striking practical explanation of the Ten Commandments. Freudenberg (2008:208) observed that Calvin, accordingly, characterises the Law as a 'rule ... for our lives' $(\mathrm{CO} 6,52)$, as it bears testimony to 'the effect of the

1.'En daarbij is heel dit onderwijs dat in de drieslag kerk, school en gezin gegeven wordt, gedragen door een theologie waarin geleerd wordt dat een mens weliswaar totaal verdorven is, maar dat Gods genade mensen totaal kan veranderen en dat Gods Geest ze tot grote daden van heiliging en vernieuwing kan aanzetten' (Selderhuys 2010:128). 
renewal of man through God's Spirit' (CO 6, 46-52). ${ }^{2}$ Calvin thus assigned 'to the Law a spiritual value as command for the born-again' [usus in renatis] (Freudenberg 2008:211). ${ }^{3}$ Although the Law cannot save, it guides and stencils a life of gratitude and sanctification in which the Christian congregation exists. ${ }^{4}$

Initially, Calvin used the Law differently. The 'written Law, given to us by God' (OS I:39.17), ${ }^{5}$ he explained in the 1536 Institutes of the Christian Religion (Christianae Religionis Institutio), directs to 'seek a way for our salvation other than through the righteousness of our works' (OS I:40.6-40.7). ${ }^{6}$ The Law was thus applied to profile the depth of 'total corruption' and to illuminate the height of the 'grace of God'. Ever since the review of the Institutes in 1539, Calvin shifted the emphasis from the initial soteriological appraisal of the Law to its role in shaping 'great deeds of sanctification and rejuvenation' in the life of the Christian believer. Freudenberg infers that Calvin's reappraisal of the use of the Law was replicated in the catechetical teaching. He (Freudenberg 2008:208) illustrated this alteration in the use of the Law by referring to the exposition of the sixth commandment in the Genevan Catechism, 'aus der Calvin die Forderung ableitet, "dass wir alle Menschen von Herzen lieben und sorgfältig darauf achten sollen, sie zu beschützen und zu bewahren"' (CO 6, 72).

In general, the appraisal of Freudenberg and Selderhuis is appropriate. However, subjecting Calvin's catechetical work, with the focus on one topic, to an in-depth investigation, exposes a more nuanced line of thinking. This is, in particular, illustrated by studying the relevant source texts in chronological order (Britz 2017:2.) It also provides the opportunity to identify patterns in Calvin's exposition that normally remains beyond the interests of investigators. One of these is the underpinning pedagogy.

For the purposes of this research, Calvin's catechetical works are consequently examined as they appeared in print between 1537 and 1551. This article thus investigates the explanation of the sixth commandment in the Genevan catechetical publications. At stake is 'You shall not kill', the commandment Freudenberg also mentions to confirm his interpretation. Apart from this, the present article is the third in a series (Britz 2014; 2017) in which the method is applied to delineate Calvin's interpretation of the Law in his catechetical teaching. The overall intention is not only to depict the theological trajectory as a development, but also to map out Calvin's pedagogy and teaching strategies. In Calvin research, this aspect of his teaching is undervalued.

2.Freudenberg (2008:208): '... die eine Wirkung der Erneuerung des Menschen durch Gottes Geist sind (CO 6,46-52)'.

3.Feudenberg (2008:211): 'als Gebot für die Wiedergeborenen (usus in renatis) ...'

4.Freudenberg (2008:209) notes: 'Das Gesetz verstand er nun konsequent im Sinne von Geboten, die der Gemeinde für ein vor Gott verantwortetes christliches Leben verpflichtend aufgetragen sind (usus in renatis), und legte die Grundlage für die reformierte Akzentuierung der Dankbarkeit und Heiligung.'

5.OS I:39.17: Dominus legem nobis scriptam posuit ...

6.OS I:40.5-40.6: quaerendam igitur aliam salutis viam, quam per operum nostrorum iustitiam.
A number of questions prompted this investigation: How did the indicated differentiation in the use of the Law, respectively before and after 1539, determine the explication in teaching the command 'You shall not kill'? Did the implementation of the two forms of use of the Law alter the scriptural justification and theological motivation underpinning the explanation respectively? Did Calvin also adjust his teaching strategy accordingly? Or is there a persistent line in the catechetical interpretation of the command in which the theological distinction mentioned had limited effect? These questions guided the analysis of this trajectory in the theological thinking and education of Calvin.

This investigation confines itself to the catechetical works of Calvin. These correspond to the Institutes which were intended as textbooks. Therefore, the trajectory 'You shall not kill', is compared with material from the Institutes, also published during the same course of time. Calvin's sermons and commentaries on the Decalogue date from after 1557, and were thus not consulted. ${ }^{7}$

This research commences with an overview of the Genevan catechetical footprint.

\section{The Genevan catechetical footprint}

The Genevan catechetical footprint comprises two distinctive texts from Calvin's hand (see also Britz 2017:4, 5). The Instruction et Confession de Foy dont on use en l'Eglise de Genève (Calvin 1537), translated in Latin as Catechismus seu christianae religionis institutio ecclesiae genevensis (1538) was the first. Saxer (1994:138-207) introduced the French text and offered a German translation. Hesselink (1997) published A commentary: Featuring Ford Lewis Battles' translation of the 1538 catechism. Annette Zillenbiller (2002:1-121 in Zillebiller \& Val 2002) edited a text-critical edition of the Instruction et confession de foy in 2002 for the new standard Ioannis calvini opera omnia series. A few years later, she (Zillenbiller 2006:97:136) also introduced and edited the French text for the Reformierte Bekenntnisschriften (Bucsay \& Busch 2006).

The second Le catéchisme de l'Eglise de Geneve: c'est à dire le Formulaire d'instruire les enfans en la Chrestienté (1542), also translated in Latin and published as Catechismus ecclesix Geneuensis, hoc est, formula erudiendi pueros in doctrina Christi (1545), received an elevated status as the core text of Calvin's catechetical materials. Ernst Saxer (1997:1-135) thoroughly introduced the Latin text, provided theological commentary and published a translation in German in the Calvin-Studienausgabe series (Busch, Heron, Link, et al. 1994). In the Reformierte Bekenntnisschriften Band I/2 15351549 (Bucsay \& Busch 2006), Saxer's introduction to and the French text of the Genfer Katechismus von 1542 were included (Saxer 2006:279-362). Earlier, Simpson (1981) offered a translation in Afrikaans for a limited reading circle in Africa.

7. Unless otherwise stated, the author is responsible for all translations and versions of original texts in the manuscript. 
To these two catechetical texts can be added La maniere d'interroguer les enfans qu'on veut recevoir a la cene Seigneur Iesus Chris [The way of questioning the children whom you wish to receive at the Supper of our Lord Jesus Christ] (CO 6:147-160). According to De Greef (2008:116-117), this questioning was first included in a 1551 booklet $A B C$ Francois, which was intended to be used in the public schools. In a footnote (CO 6:147.11-14), the editors of the Calvini Opera observed that La maniere was, for the first time, incorporated in the Genevan Catechism published in 1553. The text of the interrogation that was included in the New Testament of 1562 , they remarked, had additions. ${ }^{8}$

A fourth manuscript, L'Institution puerile de la doctrine chrestienne faicte par manière de dialogue, published in Strasbourg between 1538 and 1541, is also attributed to Calvin (OS II:60; De Greef 2008:116). Stupperich (1987:42), however, convincingly pointed out 'daß es sich hierbei um eine wörtliche Übersetzung der Summarien des Bucerschen "Kürtzer Catechismus" von 1537 handelt, die Calvin wohl nach der lateinische Vorlage durchgeführt hat'. The consideration of L'Institution puerile [The instruction for children] provided the opportunity to detect possible Strasbourg influencing of the subsequent Genevan textbooks. It is therefore considered to be part of the research.

All four texts are incorporated in the survey. This investigation embarks with Calvin's exposition of the sixth commandment in the Instruction et confession de foy, printed in Geneva in 1537.

\section{7: Instruction et Confession de Foy}

The Articles concerning the organization of the church and of worship at Geneva proposed by the ministers at the council, ${ }^{9}$ composed by Farel and Calvin (De Greeff 2008:116), were approved in January 1537 by the city's council. The third article provided for the religious education of children to be tutored by parents and guided by the pastors (Zillenbiller 2002:XI in Zillebiller \& Val 2002). To meet this mandate, Calvin published the Instruction et confession de foy in Geneva early in 1537, while a Latin translation, Catechismus seu christianae religionis institutio ecclesiae genevensis was printed the following year in Basel (Zillenbiller 2002:XII in Zillebiller \& Val 2002).

In his explanation of the sixth commandment (COR III/ $\mathrm{II}: 23.5)^{10}$ in the Instruction et confession, Calvin instructs those who are assigned to teach children that 'here we are prohibited all violence and injustice and all categories of harm that would injure our neighbour physically'

8.Co 6:147.11-14: Cette pièce se trouve pour la première fois dans le Catéchisme de 1553. Elle est reproduite dans les Manuels de 1558 et 1561. Le texte du Catéchisme dans le Nouveau Testament de 1562 a des additions que nous imprimons en italique. Nous négligeons la traduction latine dont il existe également deux récensions, la première dans les Catéchismes de 1561 et de 1563, la seconde dans une édition de premiere
1570 etc.

9.Articles concernant l'organisation de l'Eglise et du culte à Genève, proposés au conseil par les ministers.

10.COR III/II:23.5: Tu ne tueras point.
(COR III/II:23.6-7). ${ }^{11}$ He explained that these are forbidden by the commandment, 'for if we remember that man is created in the image of God, and that we need to uphold this as sacred and holy, ... the image of God is violated' when a human being is subjected to violence and injustice 'in the same way as well' (COR III/II:23.8-10). ${ }^{12}$

The Latin translation ${ }^{13}$ (COR III/II:2.1-3; see also CO 5:330.11ff.) confirms Calvin's argument. ${ }^{14}$ All violent acts and injustices of whatever kind of harm by which physical injury is committed, Calvin asserts, are prohibited by the commandment. It should be maintained, he teaches, that the human being exists in the inviolable image of God and therefore it should be upheld that transgression of the commandment violates the image of God (COR III/II:22.1-6).

Calvin's exposition reflects the prohibitions listed by him in the explanation of the sixth commandment in the Institutes of the Christian Religion (Christianae Religionis Institutio), printed in Basil the year before. In his elucidation of the Commandment, 'You shall not kill' (OS I:50.1-10), ${ }^{15}$ he then entrenched his argument in the required, and thus due to fear of and love to God. It is therefore forbidden to neither deliberately hurt, nor act unjustly or infuriate both friends and enemies. Contrarily, he explained, the command demands to exhibit kindness to both, delight them and, when in danger, to 'offer a helping hand while we strive, as far as possible, to be kind to them'. ${ }^{16}$ In his elucidation, Calvin referred to Matthew 5 (OS I:50.10), which contains Christ's disclosure of the authentic meaning of the sixth commandment. This undoubtedly informed his explanation and understanding of the command. In this regard, Calvin is no exception to the rule as applied in catechisms drafted by theologians of the Reformation.

11.COR IIIIII: $23.6-7$ : Icy nous est interdict toute violance et injure, et generalement toute offense par laquelle le corps du prochain puisse estre blesse.

12.COR III/II:23.8-10: ... car si nous avons souvenance que l'homme est faict à l'ymage de Dieu, nous le debvons avoir pour sainct et sacré, en telle maniere qu'il ne puisse estre violé qu'en luy aussi l'image de Dieu ne soit violée.

13.COR III/II:2.1-3: Catechismus seu christianae religionis institutio ecclesiae genevensis, vulgari prius idiomate edita, nuncque postremo latinitate etiam donate, loanne Calvino autore.

14.COR III/II:22.1-6: Non occides. Quo nobis violentia omnis ac iniuria, et omnino quaevis noxa, qua proximi corpus laedatur, interdicta est. Nam si hominem ad imaginem Dei meminerimus esse conditum, sacrosanctum eum habere debemus: utpote qui violari nequeat, quin imago quoque Dei violetur [Whereby we are forbidden all violence and injustices and whatever kinds of harm, that could injure the body. For, if (in as much as) we bear in mind (remember that meminero) that the human being exists in the inviolable image of God, we should uphold this: that it is the image of God that is also treated with violence].

15.OS I:50.2: Non occides [You shall not kill]. The verb occido can also be translated as to murder, to slay or to knock down.

16.OS I:50.3-4: ... quandoquidem timeri Deum a nobis atque amari oportet [Since it is obligatory or required - necessary - that God should be feared and loved by us, it follows that we ...]. This Commandment has the following consequences: 'We may not: (1) hurt (offend, injure: laedo) by being any kind of stumbling block (or causing any accidents) (OS I:50.4) to him (any person); (2) be (simus: sum: to be, to exist, live) unjust (iniurii) to anyone (OS I:50.5); (3) provoke / incite / exasperate / challenge / attack (lacesso) anyone (OS I:50.5); (4) convey (affero) force / act violent (vim) to anyone' (OS I:50.5-6).

No, much rather, if indeed there is in us fear and love towards God (si quis est in nobis timor atque amor Dei, (OS I:50.6), Calvin reiterated, 'we should to all, friends and enemies: (1) 'exhibit or present (exhibeo) beneved, 'we should to all, friends and enemies: (1) "exhibit or present (exhibeo) benevolence / kindness' (OS 1:50.7); (2) 'studiously desire (studeo) to satisfy / content / give pleasure / to please or delight (placeo) both (uter > utrisque) (friend and enemy)' (OS 1:50.7-8); (3) 'convey (affere) a helping (auxiliaris) hand to both (any of the two) if any (of the two) is in a crisis (discrimen, discriminis: manum: hand)/ is in danger' (OS 1:50.78); (4) 'strive (contendo) to be kind to both in so far we are able to be (possum)' (OS I:50.9-10). 
In general, contemporary protestant catechisms, in their explication of the sixth command, followed this biblical text. In his famed Deutsch Catechismus, Luther (1535:37-39) indicated that the meaning of the commandment is distinctly defined, because Christ unambiguously explained it in Matthew 5(p.37). ${ }^{17}$ When explicating the sixth commandment, Leo Jud in his 1534 Der grosser Catechismus [The larger catechism] taught that it not only forbids killing committed 'mit der hand, schwart un waaffen', but also includes 'aller nyd und haß, aller groll, raachirige und unwil der sich im herzen regt wider minen næchsten', as Christ himself explicated in Matthew 5 (Jud 1534:XVIII). ${ }^{18}$ In his Kurtze schrifftliche erklärung für die kinder und agohnden, published in 1534, Martin Bucer (in Stupperich 1987:53) also explained to children that the command signifies the following: 'Nit zürnen, nicht rachgyrig sein, meinem nechsten kein leid thün, weder mit wort noch wercken und folgens alles güts, wie uns das unser lieber herr Jesus leret Mat. $V^{\prime}$ (p. 132.3-6).

Informed by Christ's exposition of the command recorded in Matthew 5, all (including Calvin) denote that the commandment not only forbids homicide and physical violence, but indeed demands to secure a space of love and care where the neighbour may live a good and safe life. This command has a certain authority in life not only in terms of negative prohibitions, but in decisive duties.

In the 1536 Institutio, Calvin tied the impetus to do the command - to fear and love towards God. Fear and love of God are rooted in the relation between God and the faithful believer. In the Instruction et Confession, the theological provocation that guides his Matthew-5-informed interpretation of the command is the image of God. The image of God, in which humans exist, is a theological concept associated with and embedded in creation. It points to the most fundamental and inherent existential aspect of human life. Man and woman are created in the image of God.

However, in the introductory paragraphs of the 1536 Institutio, Calvin related this concept to the fall (OS I:38.2 ff.). He emphasised that Adam, the father of all, was created in the image and likeness of God (Gn 1:26) and was thus endowed with wisdom, righteousness and holiness (OS I:38.2-4).${ }^{19}$ When he fell into sin, this image and likeness were impaired and obliterated (OS I:38.7-8). ${ }^{20}$ Adam lost all the blessings of the grace of God. This is the fruit of sin, Calvin concluded. Adam's descendants, he continued, are all corrupted and deprived of all things good and therefore deserve the judgement and eternal punishment of God. They consequently lack the ability to obey God's commandments.

17.For Luther (1535:37), it boils down to nemlich / das man nicht toedten sol wider mit hand / herzen / mund / zeichen / geberden / noch huülffe und rath.

18.Jud also refers to Ephesians 4, Romans 12 and 1 John 3 in this respect. Also wird dem menschen in disem verbott aller nyd un haß, aller fræffler, gwalt, todschlag und gebrucht mag warden, verboten (Jud 1534:XVIII). The shedding of innocent blood is an abomination to the Lord, Jud teaches with reference to Genesis 9 and Ezekiel 24.

19.OS 1:38.2-4: ... parentem omnium nostrum Adam esse creatum ad imaginem et similitudinem Dei (Gen 1), hoc est, sapientia, iustitia, sanctitate praeditum, ...

20.0S I:38.7-8: haec imago et similitudo Dei inducta et obliterata est ...
Therefore, God's Law teaches them to seek the way of forgiveness of sins for their salvation (OS I:39.40-40.7) in order for the image of God to be restored. Calvin here exploited the concept in terms of the 'demolished' image of God in human beings and underlined the soteriological consequences.

In the explanation of the sixth commandment in the Instruction et Confession, the gravity of his argument shifts to an anthropological emphasis and motivation. Transgression of the sixth commandment is a violation of the intact image of God in human beings and their existence. The commandment protects and shields the image of God in humans. This use of the concept image of God in 1537 represents the inception of a significant trajectory in Calvin's anthropology. ${ }^{21}$

In the Institutio, the theological foundation (fear and love towards God) served as a condition for carrying out the commandment. In the Instruction et confession, the image of God is used as a consequence of keeping the commandment. In 1536, Calvin's explanation included both the prohibitions and implied duties associated with the command, while, in 1537 , it is restricted to the prohibitions.

In 1538, Calvin and Farel had to leave Geneva. Calvin joined Bucer in Strasbourg where he ministered to the French congregation in the city. He also reviewed the Institutio and completed the Commentary on the Letter to the Romans.

\section{8/41: I'Institution puerile de la doctrine Chrestienne}

In Strasbourg, Martin Bucer had initiated a catechetical tradition. In his extensive editorial work on Martin Bucers Deutsche Schriften, Stupperich (1987:19-49) devoted volume 6(3) to Martin Bucers Katechismen aus den Jahren 1534, 1537, 1543 in which this catechetical tradition took shape. His Kurtze schrifftliche erklärung für die kinder und agohnden, published in 1534, is fundamental. This was followed by Der Kürtzer Catechismus und erklärung (Bucer 1537 in Stupperich 1987) and Der Kürtzer Catechismus (Bucer 1543 in Stupperich 1987).

Calvin used l'Institution Puerile de la Doctrine Chrestienne faicte par Maniere de dialogue (OS II:152-157) to teach the children of the French-speaking congregation in the city. This Instruction for children was published between 1538 and 1541 (De Greef 2008:116). As mentioned earlier, it was most probably a French translation of a Latin version of the 1537-Bucer text; in

\footnotetext{
21.In the 1539 edition of the Institutes, Calvin would expound the theme. A few years later his Commentary on Genesis 1:26 and 27 carried his thinking further. A comparison of the consecutive editions of the Institutio clearly indicates a development in Calvin's thinking on this point. The final version of his thinking was encapsulated in the 1559 edition (see OS III:173.27ff.; 179.32-45; 180.35-40). Obviously, the 1554 Commentary on Genesis (CO 23:25-27) should also be consulted to properly map out this development of thought. Calvin then observed: CO 23:26: Quoniam deleta est imago Dei in nobis per lapsum Adae, ex reparatione iudicandum est qualis fuerit. Dicit Paulus nos per evangelium transfigurari in imaginem Dei. Et secundum ipsum regenerate spiritualis nihil aliud est quam eiusdem imaginis instauratio (Col 3,10 et Ephes. 4, 23). Quod autem earn constituit in iustitia et sanctitate veraci, est synecdoche: nam quamvis illud prarn constituit in iustitia et sanctitate veraci, non tamen est totum. Ergo hac voce designatur totius naturae integritas, quum Adam recta intelligentia praeditus foret, affectus haberet compositos ad rationem sensus omnes sanos et ordinatos, verea thought is that the image of God had been destroyed in us by the fall of Adam. According to Paul, the gospel transforms us into the image of God. Spiritual regeneration is nothing else than the restoration of the image of God.
} 
particular, the Kürtzer Catechismus' exposition of the command to the young children (see Stupperich 1987:220.27-33). ${ }^{22}$

The Instruction for children is shaped in the form of a dialogue (par maniere de dialogue) between the minister (Le Maistre) and the child (Lenfant). Through questions and answers, the booklet offers a concise explanation of the creed (OS II:152.15154.21), the Lord's Prayer (OS II:154.22-156.4) and the Decalogue (OS II:156.5-157.34). The Bucer-Strasbourg trajectory of teaching the Christian faith deployed its instruction thus in the order of the creed, prayer and law. This differed from the traditional Lutheran-oriented law-creed-prayer sequence, which Calvin also adhered to in Geneva in 1536 and $1537 / 1538$. Freudenberg, by the way, alludes to this difference in his comments on Calvin's explanation of the sixth commandment in the Genevan Catechism (see Freudenberg 2008:209).

The third section of the Instruction for children is devoted to the Decalogue. The last five commandments - Les commandmens de charite envers ceux qui nous sont coniointz - are clustered together (OS II:157.2-3). The minister asks: 'What do these commandments of the Lord entail?' The answer comprises that 'we are enjoined' to bear no harm to anyone, whether in thought, in speech, in deeds, and neither to deny them the joy of life nor to cause injury to his body, his wife, his children, his property and his good reputation (OS II:157.5-10). ${ }^{23}$ The minister then is interested in hearing which of these aspects indicate that physical injury to a person is not allowed (OS II:157.10). ${ }^{24}$ The answer is: 'The sixth. You shall not kill' (OS II:157.10-11).

The ultimate questions of La tierce partie (OS II:156.5) of the Instruction for children concentrate on the fulfilment of and compliance to the duties of the Law in daily living. Children are confronted with doubt, put forward as an inquiry: 'Can you, however, reach in this life such great perfection' in impeccable observance of the commandments? (OS II:157.2627). ${ }^{25}$ 'Our nature is so corrupt with perversion that the only remission of sin and righteousness come from Christ. ${ }^{26}$ The minister guides them to certainty, 'put all your trust in Him and stay in Him' (OS II:157.29-30). ${ }^{27}$ In him, there is no condemnation by the Law. Therefore, 'the desire and affection

22.'Für die gar Jungen' ['For the little ones'] (Stupperich 1987:219.27).

23.OS II:157.5-10: M. Que deffendent ces commandemens du Seigneur? L. J/z nous commandent de ne porter aulcun dommage a personne, soit en pensee / en parolle / en faict / ou omission de plaisir. et que ie ne face iniure a son corps a sa femme a ses enfans a ses biens ne a sa bonne renomee [We are enjoined: (1) to femme a ses enfans a ses biens ne a sa bonne renomee (We are enjoined: (1) to them the joy of life (omission of pleasure) and (3) that I do not injure (by facing or them the joy of life (omission of pleasure) and (3) that I do not injure (by facing or
confronting) his body, his wife, his children, his property and his good reputation] confronting) his body, his wife, his children, his property and his good reputation].
In Bucer's 1537 Kürtzer Catechismus, the answer to the minister's question concerning the meaning of the last five commandments, entailed: 'Er verbeute alle gedancken, wort, thün und lassen, dadurch mein nehister möchte in einigen weg beschediget oder beleidiget werden an seinem leib, seines weibs und kinderen, an der narung und an glimpff und ere' (Stupperich 1987:220.14-17).

24.Par quelles parolles deffend il ne faire iniure au corps? [According to which words to injure/insult/abuse the body are not allowed?] (OS II:157.10).

25.OS II:157.26-27: Mais peuls tu parvenir en ceste vie presente en si grande perfection?

26.OS II, 157.27-29: Nostre nature est si corrumpue quelle n'a aulcun bien mais toute remission de peche et toute iustice viennent de Christ.

27.OS II:157.29-30: Mets doncques toute ta fiance en luy suel \& demeure en luy ... towards his Law will be inflamed in you', the Instruction affirms (OS II:157.31-32). In all these things, the minister concludes, 'we must give honour and glory forever to our Lord Jesus Christ. Amen' (OS II:157.32-34). ${ }^{28}$

The outcomes of teaching the command are quite clear. No justification before God can be warranted by obeying the Law. The Law indeed condemns. The longing for and warmth towards the Law, however, is kindled by the righteousness of Christ who fulfilled the commandments. This opens an enthralling perspective on the relevance of the Law in the believer's life. The righteousness of Christ ignites doing the command. The cause for doing the command resides in Christ and his righteousness. Christ's unique dealing with the very Law acts as the foothold to observe the implications of the command in daily life. This comprehension of the Law in the believer's life is confirmed by the order in which the Christian faith is taught in the Instruction of children, namely creed, prayer and the Decalogue.

The Instruction for children undoubtedly epitomises the Bucerian catechetical tradition. The method of teaching and learning is shaped by questions and answers. As an effective cooperative teaching strategy, the inquiry-based instruction poses thought-provoking questions which inspire candidates to think for themselves and become more independent learners. This strategy encourages pupils to participate in learning by investigating their ideas and thinking. This would improve their problem-solving skills and challenge them to gain a deeper understanding of the issue at stake, namely the presence of Christ in the life of the believer. This presence of Christ as the One who fulfilled the commandments is inextricably embossed on a life of gratitude.

With the review of the Institutio and its translation into French completed, the end of Calvin's stay in Strasbourg arrived. In 1541, on invitation, he returned to Geneva. Did he incorporate this line of education in his catechetical works to be published in Geneva? And, to what extent?

\section{2: Le Catéchisme de l'Eglise de Genève}

In Geneva, Calvin drafted for the city and its church(es) Le Catéchisme de l'Eglise de Genève, c'est a dire le Formulaire d'instruire les enfants en la Chrestiente (CO 6, 1-134). The Latin edition was published in 1545 entitled Catechismus ecclesix Geneuensis, hoc est, formula erudiendi pueros in doctrina Christi (OS II:72-151). The catechism is intended as a formula of uniformity to duly instruct the children in the doctrine of

28.OS II:157.32-34: Toutes ces choses te vueille donner nostre Seigneur JESUSCHRIST: Auquel soit honneur et gloyre a iamais. AMEN. In Bucer's Kürtzer Catechismus (1537) this was formulated as follows: U. Kanstu aber auch dise volkommenheit in diser zeit erlangen? $K$. In unserem fleisch ist nichts güts, in Christo aber, meinem Herren, ist verzeihung der sünden und alle gerechtigkeit. U: Dem glaube, an den halte dich, der nimmet dir hin den flüch des gesatzes, dem du nimmer gnüg thüst. Der gibet dir auch, sein gesatzt zü lieben und in demselbigen zü tichten tag und nacht, und screibet es dir ins hertz. Dis alles verleihe dir er unser Herr und einiger Heiland. Dem seie ere und preis in ewigkeit. Amen (Stupperich 1987:220.27-33) Heiland. Dem seie ere und preis in ewigkeit. Amen (Stupperich 1987:220.27-33) For the older children, Bucer answered the question about what the sixth commandment requires, similarly: Das ich wider meinen nehisten nimmer zürne oder im leids zü thun gedencke' (Stupperich 1987:217.9-10). And, then he posed the existential question. When do you 'live this Commandment? Wann ich Got, den Herren, ob allen dingen, und meinen nehisten als mich selb liebe und keinen
unwillen noch rachgirigkeit gegen jemand habe, man thü mir, was man wölle. U: Dem gebe dir der Herre trewlich nachzukommen (Stupperich 1987:217.12-15). 
Christ. Calvin now systematised the material in a new order of creed, law and prayer. He amended the order law, creed and prayer as deployed in the 1536 Institution and 1537 Instruction et Confession. His perception of the function of the Law in the believer's life is adjusted accordingly. Among unbelievers, the Law achieves nothing more than to shut them out from all pardon before God (OS II:111.24-26).

As regards believers, the Law has a threefold use, he taught. Firstly, the Law teaches them that righteousness cannot be obtained by good works. This knowledge prepares them for seeking salvation in Christ. Secondly, as they are not able to perform its requirements, the Law urges them to seek strength from the Lord, reminding them of their perpetual guilt. Finally, it is like reins by which they are kept in the fear of the Lord (OS II:111.29-112.5) ${ }^{29}$ Back in Geneva, the teaching of the Law to children was now determined by Calvin's definition of the Law as the rule set by God for life (OS II:96.9). ${ }^{30}$ Therefore, it must be assumed that the sixth command was interpreted within this frame of reference. Freudenberg (2008:209) is convinced that it was the case.

Partially following the Strasbourg structure and format, the teaching of the sixth commandment entails two questions, as well as a statement to which the student must respond. This method of teaching integrates a cooperative learning strategy that allowed for verbally expressing ideas and responding to others. This would develop the learners' confidence, reflection, as well the enhancement of their communication and thinking skills which were vital to master the intended outcomes of the teaching. This is an evident indication of Strasbourg influence.

The first question is formulated to provoke reflection and preoccupy the learner with the deeper meaning of the command: 'Does this commandment forbid nothing more than the perpetration of homicide?'(CSt 2:74.12) ${ }^{31}$ The answer is emphatic: 'Yes indeed'. There is undeniably more to it than the prohibition of murder. For, when God speaks here, 'He not only restricts by law our outward works, but also the affections of the mind, and indeed to them chiefly' (CSt 2:74.13-14). ${ }^{32}$ The teacher accordingly concludes that the learner insinuated that 'there is some kind of stealthy murder from which God calls us away'. The response confirms. 'So is it. For anger, and hatred and all desire to hurt someone is murder in the sight of God' (CSt 2:74.17-18)..$^{33}$ In his exposition, Calvin is guided by the interpretation Christ gave to the command (Matt. 5).

\subsection{S il:111.29-112.5: Q 118. ... Principio, dum iustitiam operibus consequi se non posse ex ea discunt, ad humilitatem hoc modo erundiuntur quae vera est ad quaerendam in Christo salutem praeparatio. Deinde quatenus plus multo exigit ab ipsis, quam fuit praestando, eos ad petendam a Domino virtutem sollicitat, simulque perpetui reatus commonefacit, ne superbire audeant. Postremo fren instar illis est, quo in Dei timore retineantur.}

30.0S II:96.9: Q 131. Quam autem vivendi regulam nobis posuit?

31.CSt 2:74.12: Nihilne aliud vetat, quam caedes perpetrare?

32.CSt 2:74.13-14: Nam cum hic loquatur Deus, non externis tantum operibus legem dicit: sed animi etiam affectibus; adeoque his potissimum. RB 326.10-12: Car puis que c'est Dieu qui parle, non seulement il nous impose Loy sur les oeuvres que c'est Dieu qui parle, non seulement il nous impose Loy sur
exterieures: mais principallement sur les affections de nostre cueur.

33.CSt 2:74.17-18: Ira enim et odium, et quaevis nocendi cupiditas, ceades coram Deo censetur. RB 326.17: Voire: qui est haine et rancune, et cupidité de mal faire d̀ nostre prochain.
The second question ensues: 'Have we done enough if we do not hate anyone?' The answer again is strongly denied.

No, by no means. Since the Lord, by condemning hatred and restraining us from any harm by which our neighbour may be injured, shows at the same time that He requires us to love all men from the heart, and faithfully commit to defend and preserve them (CSt 2:74.20-23)..$^{34}$

This statement to love all men must be understood with reference to questions and answers 221-223. There, Calvin reflected on the unity of humankind. He argued that all human beings are miraculously connected 'to us' with the bond by which God has tied all mankind together. This is a sacred, inviolable and Divine arrangement that cannot be destroyed by depravity or evil (OS II:110.25-111.4).

Careful reading discloses that the exposition of the sixth commandment in the Catechismus Ecclesiae Genevensis represents a concise summary of the interpretation articulated in the revised edition of the Institutio Christianae Religionis, which appeared in print in 1539. In this edition, now comprising four books, Calvin considered the Law in the second book, Of the knowledge of God the Redeemer in Christ, as first manifested to the fathers in the Law and thereafter to us under the Gospel (OS III:228.3-5).$^{35}$ Chapter 7 is devoted to the Law, 'given to keep alive the hope of salvation in Christ', until his advent, he stated (OS III, 326.19-21; see also Britz 2017:6-7). The sixth commandment is explained in two paragraphs (OS III:379.28-380.39).

Because God has joined all of humankind together by a certain unity or common accord (OS III:379.30), ${ }^{36}$ the purpose of the command, Calvin wrote, is that each should concern himself (commendatam) with the safety or 'security' (incolumitatem) of all. Accordingly, all violence, injustice and maltreatment that may injure the neighbour physically (OS III:379.33-380.2), ${ }^{37}$ are forbidden. 'You shall not kill' also prohibits murder committed by the heart and bids 'the inner intent to preserve a brother's life', ${ }^{38}$ Calvin observed. The hand gives birth to murder, but the mind, inflicted with anger and hatred, conceives it. If one persists in these thoughts, he concludes, the Spirit has already declared that 'he who hates a brother in his heart, is a murderer' (1 Jn 3:15). The Lord Christ has declared in Matthew 5:22 that, whoever is angry with his brother, is liable to judgement: 'whoever says Raca, is liable to council, whoever says you fool, is liable to the hell of fire' (OS III:380.17-22).

Scripture notes, Calvin continued, that this commandment is supported by a twofold basis: A human being is the 'image

34.CSt 2:74.20-23: ... siquidem Dominus odium damnando, et nos arcendo a quavis noxa, qua proximus noster laedatur, simul hoc se exigere ostendit, ut omnes mortales ex animo diligamus, ac fideliter ipsis tuendis conservandisque studeamus. RB 326.21-23: Non. Car Dien, en condemnant la haine, signifie qu'il requiert que nous aymions noz prochains, et procurions leur salut, et le tout de vraye affection et sans feintise.

35.0S III:228.3-5: De Cognitione Dei Redemptoris in Christo, quae Patribus sub Lege primum, deinde et nobis in Evangelio patefacta est.

36.OS III:379.30: hominum genus unitate ...

37.0S III:379.32-380.2: ... violentia omnis et iniuria, ac omnino quaevis noxa, qua proximi corpus laedatur, nobis interdicitur. '... our neighbour's body'.

38.0S III:380.11-12: ... conservandae fratris vitae. 
of God' and concurrently 'our flesh' (OS III:380.24). ${ }^{39}$ By flesh, Calvin indicates that, if 'we do not wish to renounce (exuere) all humanity, we ought to cherish his as our flesh'.40 Underlying and decisive is Christ's summary of the second table of the Law, namely to love the neighbour as yourself (Mt 22:37). The command requires, in the preservation of life, to revere God's image which is imprinted in man and 'to embrace our own flesh in our neighbour' (OS III:380.3031). ${ }^{41} \mathrm{He}$ who has merely refrained from shedding blood has therefore not yet avoided the crime of homicide. If someone, Calvin wrote, perpetrates anything by deed, plots anything by an attempt, wishes or plans anything contrary to the safety of the neighbour, he or she is considered by God to be guilty of murder. 'Unless we endeavour to protect the safety of our neighbour according to our ability and opportunity (as far as it is possible and appropriate), we have inhumanly violated the law' (OS III:380.34-36; see also OS III:380.2-6)..$^{42}$

Typifying phrases in the Institutio Christianae Religionis such as 'God has joined all of humankind together by a certain unity or common accord', all violence, injustice and maltreatment that may injure the neighbour physically are forbidden, the inner intent to preserve a brother's life, 'we do not wish to renounce all humanity, we ought to cherish his as our flesh', in the preservation of life, to revere God's image which is imprinted in man and 'to embrace our own flesh in our neighbour', resonate in the Catechismus Ecclesiae Genevensis. Remarks in the Catechismus such as 'to love all men from the heart', 'For anger, and hatred and all desire to hurt someone is murder in the sight of God', 'He not only restricts by law our outward works but also the affections of the mind', 'there is some kind of stealthy murder from which God calls us away' and 'faithfully commit to defend and preserve them', clearly indicate the connection. This confirms that Calvin summarised the 1539 exposition of 'You shall not kill' in the Genevan Catechism. Strikingly, there is no direct reference to the foundation of the commandment in the image of God and the flesh of the neighbour in the latter texts. However, this is implied. It also reminds of his explication in 1537 when he motivated the duties encapsulated in the command in terms of the image of God.

The ultimate text of the investigation was first published in the 1550s, entitled The way of questioning the children whom you wish to receive at the Supper of our Lord Jesus Christ.

\section{1: La maniere d'interroger les enfants}

La Maniere's d'Interroguer les enfans is designed to assess children who should be admitted to receive the Lord's Supper. It comprised 21 questions and is divided into five 39.0S III:380.24: ... quia et imago Dei est homo, et caro nostra.

40.0S III, 380.26-27: ... nisi omnem exuere humanitatem, ut carnem propriam fovere debemus.

41.OS III:380.30-31: ... ut et suam imaginem in ipso impressam revereamur, et carnem nostram amplexemur.

42.0S III:380.34-36: Nisi rursum illam pro facultate et opportunitate tueri studes, ea quoque immanitate Legem praevaricaris. sub-sections. The first deals with the creed and its contents. Then follow a few questions: firstly, on the Ten Commandments; and secondly on the significance of Christ's merits as the basis for man's salvation, trailed by prayer and the sacraments with emphasis on the Lord's Supper and the proper reception thereof. The second sub-section deals with the Ten Commandments and their inevitable value in the believer's life. The questions concerning the commandments are articulated in such a way that they channel the applicant to confessing her or his belief in the crucified Christ. They are formulated responsive to the candidate's knowledge and support transformative learning. By verbally expressing their ideas in responding to the questions, the candidates should be able to demonstrate their conviction and reflection in understanding the issue at stake.

The first question is insistent: 'Should God be served according to His Commandments, or should He be served according to the traditions of men?' The answer is obvious: 'Not according to the commandments les hommes, but according to those of God' (CO 6:154.3-7). Subsequently, candidates are required to recite the Ten Commandments and indicate where they are recorded in Scripture. Then follows Peus-tu accomplir les commandemens de Dieu de toymesme? Non (CO 6:156.3-6). The interviewee has to face the truth that she or he cannot fulfil God's commandments by her- or himself or own efforts. The next question indicates a means away from this dead-end: 'Who is it that accomplishes them in you?' (CO 6:156.8). The answer is: 'The Holy Spirit' (CO 6:157.3).

The inquiry-based teaching strategy challenges applicants to think for themselves and to articulate the underpinning problem. The next question is whether one 'can perfectly accomplish the commandments when God has given you his Holy Spirit?' The answer is a definite, 'not at all' (CO 6:157.5-8). This line of thinking corresponds with questions 121 and 122 of the 1545 Catechism. Works do not have virtue in their own worthiness, even though they proceed from the Holy Spirit. They are always mixed up with a degree of contamination due to the weakness of the flesh and therefore flawed (OS II:94.6-12). ${ }^{43}$ In La Maniere, the purpose is to confront the applicant with the next statement: 'And all the while God denounces (or dooms) and rejects all those who will not entirely fulfil his commands. This is to be recognised as the truth' (CO 6:157.9-13). ${ }^{44}$ Obedience to the Law is not an arbitrary matter. At the same time, all efforts to fulfil the commandments are inefficient to bring about salvation. This dilemma is formulated in the next question: 'By what means will you be saved, and delivered from the curse of God?' The answer should be known: 'Through the death and suffering of our Lord Jesus Christ'. (CO 6:157.14-19). ${ }^{45}$ The subsequent explication is apparent: 'Because, by his death, He has restored us to life and has reconciled us with God his Father,

43.0s i1:94.11-12: At nonnihil semper inquinamenti ex infirmitate carnis admixtum est, quo vitiantur.

44.CO 6:157.9-13: Et toutesfois Dieu mauldit et reiecte tous ceux qui ne parferont entierement ses commandemens.

45.CO 6:157.14-19: Par la mort et passion de nostre Seigneur lesus Christ. 
and as Paul said, he died for our sins and is resurrected for our justification' (CO 6:157.23-24-158.2-3).

Strictly speaking, La Maniere's d'Interroguer les Enfans is not intended to facilitate catechetical instruction, but rather to guide admission the sacrament of the Lord's Supper. Catechetical instruction is assumed to have been completed. The Decalogue is also not interpreted as in other catechetical materials. The use of the Law in the La maniere d'interroger les enfants, as well as the role that Calvin attributes to it in the life of the believing child should, however, be noticed. The underlying argument indicates that the Law is given as a standard to serve God in daily life. This can only be achieved through the work of the Holy Spirit in the believer. However, despite the indwelling of the Holy Spirit, the Law could not yet be fully observed. The only ground for salvation is the allinclusive satisfaction of Christ on the cross. In this way, Calvin builds the argument to reach an appropriate point to engage with the explication of the Lord's Supper.

In this trajectory, the Law is undoubtedly used as a rule of life for the born-again, as Freudenberg indicated in his explication of the teaching of the Law in the Genevan Catechism. However, it is fundamentally qualified by the work of Christ the Redeemer. The indwelling of the Holy Spirit does not compromise the sacrifice of Christ. The inadequate compliance with the Law thus directs the Children whom you wish to receive at the Supper of our Lord Jesus Christ to the Lord of the table. The Law is more than a rule for a devout and holy life.

\section{Conclusion}

The exploration of Calvin's explanation of the sixth commandment in his catechetical works, commenced with Instruction of 1537/1538, followed by l'Institution puerile de la doctrine Chrestienne (1538-1541), the 1542/5 Catéchisme and in conclusion, by way of reflection, La maniere d'interroger les enfants (1551).

His teaching of the command to children is deeply ingrained in the understanding and enduring meaning Christ gave to 'You shall not kill'. In the 1555 published Harmonia ex tribus Evangelistis composite, Mattaeo, Marco et Luca, Calvin explicitly wrote (explaining $\mathrm{Mt}$ 5:21) that Christ is the faithful expounder of the command (and Law). His interpretation clarifies the nature of the Law, its object, and its extent (CO 45:174.6-10). ${ }^{46}$ In this respect, Calvin's thought is not unique. As was indicated, he followed the typical trend in the protestant interpretation of the command 'You shall not kill'. The life in Christ is moulded by what is prohibited and demanded by the commandment. In both aspects, like Luther, Jud, Bucer and Calvin have shown, the contours of life in Christ are delineated.

Calvin employed and developed with regard to his understanding of the sixth commandment a perspective that

46.co 45:174.6-10: Neque enim fingendus est Christus novus legislator, qui ad aeternam patris sui iustitiam aliquid addat, sed tanquam fidus interpres audiendus est, ut sciamus qualis sit lex, quorsum tendat, et quousque pateat. gave his explanation a significant theological frame of reference. In the Instruction et confession (1537/1538), he linked contravention of the commandment to the violation of the image of God in fellow human beings. So the command intends to protect the image of God in human beings. In his clarification of the commandment in the 1539 edition of the Institutes, he consigns the protection of the image of God to Christ's abridgement of the second table of the Law, recorded in Matthew 22:39, namely to love your neighbour as yourself, as your own flesh. Matthew 22:21, 22 and 39 are therefore the fundamental source that significantly determined Calvin's interpretation of the sixth commandment. His exposition should not without qualification be attributed to the use of the Law as a rule of life for the born-again (usus in renatis Freudenberg), as reigns by which they are kept in the fear of the Lord. An in-depth reading of the trajectory of explanation of the sixth commandment that began in 1537, disclosed the emerging of insights, accents and a theological concept that highlights a dynamic and integrated significance of the Law in Christian life.

What can be concluded from this exposition of the sixth commandment about the theory of education that Calvin deployed? What does the method he utilised in teaching children reveal about his pedagogy? It is apparent that Calvin not only envisioned the dynamic transfer of knowledge. The knowledge content is unpacked in practical competencies and skills to live a spontaneous Christian life. In this sense, a dynamic pedagogy and educational theory guides the learner by asking challenging questions to consider and think, and then to respond independently. Calvin's dynamic pedagogy intends the spontaneous creation of an existential eagerness to learn, a committed studiousness in those subjected to his teaching material. His teaching theory is determined by the inherent subtleties and dynamics of the learning contents he transmits and opens to his students. It is facilitated in a cooperative learning strategy characterised by an approach that is responsive to the learning needs and styles of children and thus supports transformative learning. The introduction of the inquiry-based instruction a (question and answer) format in 1542 represents a significant development in this regard. The teaching strategy no longer accommodates the cooperative reception and explanation of a summary of the main features of the Christian doctrine as Calvin utilised in the 1537 Instruction et confession. Since his return to Geneva, it encouraged learners to participate in asking questions and investigate and assess their ideas.

\section{Acknowledgements Competing interests}

The author has declared that no competing interest exists.

\section{Author's contributions}

The author is responsible for all underpinning original research, the compilation of the argument, conceptualisation in written format and the included referencing. 


\section{Ethical considerations}

This article followed all ethical standards for research without direct contact with human or animal subjects.

\section{Funding information}

This research received no spesific grant from any funding agency in the public, commercial, or not-for-profit sectors.

\section{Data availability}

Data sharing is not applicable to this article as no new data were created or analysed in this study.

\section{Disclaimer}

The views and opinions expressed in this article are those of the author and do not necessarily reflect the official policy or position of the UFS.

\section{References}

Britz, D., 2017, ‘A life cultivated by righteousness: Calvin's exposition of the eighth commandment in teaching children', KOERS - Bulletin for Christian Scholarship 82(2), 1-14. https://doi.org/10.19108/KOERS.82.2.2347

Britz, R.M., 2014, 'Calvin's instruction of the fifth commandment', KOERS - Bulletin for Christian Scholarship 79(4), 1-8. https://doi.org/10.4102/koers.v79i4.2174

Britz, R.M. \& d'Assonville, V.E. (eds.), 2009, 'Preface: Calvin as catechist: Congress volume with contributions delivered at the 8th South African Congress on Calvin Research, Bloemfontein, 2-4 September 2008', KOERS - Bulletin for Christian Scholarship 74(4), xiii-xxiv. https://doi.org/10.4102/koers.v74i4.138

Bucer, M., 1534, 'Kurtze schrifftliche erklärung für die kinder und agohnden. Der gemeinen artickeln unsers christlichen glaubens. Der Zehen gebott. Der Vatter unsers. Hierin findestu einseltigen christlichen bericht aller stucken die einem christen nutz und not zuwillen seind. Durch die Prediger und diener der gemein zu Straßburg, 1534', in R. Stupperich (Hrsgs.), 1987, Martin Bucers Deutsche Schriften Band 6,3. Martin Bucers Katechismen aus den Jahren 1534, 1537, 1543, pp. 51 173, Gütersloher Verlagshaus Gerd Mohn, Gütersloh.

Bucer, M., 1537, 'Der Kürtzer Catechismus und erklärung der XII stücken Christlichs glaubens. Des Vatter unsers unnd Der Zehen gepotten. Für die Schüler und andere kinder zü Strasburg. Durch die Prediger daselbet gestellet. M.D. XXXVII', in R. Stupperich (Hrsgs.), 1987, Martin Bucers Deutsche Schriften Band 6,3 Martin Bucers Katechismen aus den Jahren 1534, 1537, 1543, Gütersloher Verlagshaus Gerd Mohn, Gütersloh.

Bucer, M., 1543, 'Der Kürtzer Catechismus. Das ist Christliche underweisung von den Articklen unsers Glaubens, Vatter unser, Zehen Gebotten, H. Sacramenten Und anderen Christlichen Kirchenzucht und übungen. Für die Schüler und andere kinder zü Strassburg M.D. xliii', in R. Stupperich (Hrgs.), 1987, Martin Bucers Deutsche Schriften Band 6,3. Martin Bucers Katechismen aus den Jahren 1534, Deutsche Schriften Band 6,3. Martin Bucers Katechismen aus
1537, 1543, Gütersloher Verlagshaus Gerd Mohn, Gütersloh.

Bucsay, M. \& Busch, E. (Hrsgs.), 2006, Reformierte Bekenntnisschriften Band I/2 1535-1549, Neukirchener Verlag, Neukirchen.

Busch, E., Heron, A., Link, C., Opitz, P., Saxer, E. \& Scholl, H. (Hrsgs.), 1994, CalvinStudienausgabe, Band 1: Reformatorische Anfänge [1533-1541], Teilband 1/1, Neukirchener Verlag, Neukirchen.

Calvin, J., 1537, 'Instruction et confession de foy dont on use en l'Eglise de Genève', in E. Busch, A. Heron, C. Link, P. Opitz, H. Saxer \& H. Scholl, H. (Hrsgs.), CalvinStudienausgabe, Band 1: Reformatorische Anfänge [1533-1541], Teilband 1/1, ptudienausgabe, Band 138-207, Neukirchener Verlag, Neukirchen.
Calvin, J., 1863-1900, 'Joannis Calvini opera quae supersunt omnia', in G. Baum, E. Cunitz \& E. Reuss (eds.), Corpus Reformatorum, pp. 1863-1900, Schwetschke, Braunschweig.

Calvin, J., 1926-1962, 'Joannis Calvini opera selecta', in E.P. Barth, G.(W). Niesel \& D. Scheuner (eds.) Monachii in Aedibus, vols. I-V, pp. 1926-1962, Chr. Kaiser, München.

Calvin, J., 2002, Joannis Calvini opera omnia III. Scripta Ecclesiastica II. Instruction et confession de foy dont on use en l'Eglise de Genève. Catechismus ecclesiæ Geneuensis, hoc est, formula erudiendi pueros in doctrina Christi, Genève.

CO, see Calvin, J., 1863-1900.

COR, see Calvin, J., 2002.

CSt 2, see Saxer, E., 1997.

De Greef, W., 2008, The writings of John Calvin, expanded edition. An introductory guide, transl. L. Bierma, Westminster John Knox Press, Louisville, KY.

Freudenberg, M., 2008, 'Katechismen', in H. Selderhuis (Hrsg.), Calvin Handbuch, pp. 204-212, Mohr Siebeck, Tübingen.

Hesselink, J., 1997, Calvin's first catechism: A commentary: Featuring Ford Lewis Battles' translation of the 1538 Catechism, Westminster John Knox, Louisville, KY.

Jud, L., 1534, Der groesser Catecchismus Christliche klare und einfalte ynleitung in den Willen un in die Gnad Gottes darinn nit nun die Jugedtsunder ouch die Eltern underricht wie sy jre find inb den gebotten Gottes in Christichem glouben und rechten gebætt under wy sen mœgend. Geschriben durch Leonam Jude diener ders worts der kilchen Züriych, n.p., s.l.

Kingdon, R., 2004, 'Catechesis in Calvin's Geneva', in J. van Engen (ed.), Educating people of faith: Exploring the history of Jewish and Christian communities, pp. 294-313, Eerdmans, Grand Rapids, MI.

Kloosterman-Van der Sluys, A.G., 2009, 'Calvyn en de jeugd: Kinderen en jongeren in de theologie van Johannes Calvijn', in K. Appeloo-Boersma \& H.J. Selderhuis (eds.), Calvijn in de Nederlanden, pp. 150-167, Instituut voor Reformatieonderzoek, Apeldoorn.

Luther, M., 1535, Deutsch Catechismus Mit einer newen Vorrhede / und vermanunge zu der Beicht. Mart. Luther, Wittenberg, s.I.

Pitkin, B., 2001, “"The Heritage of the Lord”. Children in the Theology of Calvin', in M.J. Bunge (ed.), The child in Christian thought, pp. 160-201, Eerdmans, Grand Rapids, MI.

Saxer, E., 1994, 'Genfer Katechismus und Glaubensbekenntnis (1537)', in E. Busch, A. Heron, C. Link, P. Opitz, E. Saxer \& H. Scholl (Hrsgs.), Calvin-Studienausgabe Band 1 Reformatorische Anfänge (1533-1541) Teilband 1/1, pp. 131-137, 138-207, Neukirchener Verlag, Neukirchen.

Saxer, E., 1997, 'Der Genfer Katechismus von 1545', in E. Busch (Hrsg.), CalvinStudienausgabe Band 2. Gestalt und Ordnung der Kirche, pp. 1-9, 9-135, Neukirchener Verlag, Neukirchen.

Saxer, E., 2006, 'Genfer Katechismus von 1542', in M. Bucsay \& E. Busch (Hrsgs.) Reformierte Bekenntnisschriften Band I/2 1535-1549, pp. 279-362, Neukirchener Verlag, Neukirchen.

Selderhuis, H.J., 2010, 'Calvijn en de jeugd van de kerk', in E.A. De Boer \& P. Van de Breevaart (eds.), De onbekende Calvin. Een veelkleurig portret, pp. 121-128, Uitgeverij Kok, Utrecht.

Simpson, H.W., 1981, Calvyn se kategismus, Potchefstroomse Teologiese Publikasies, Potchefstroom.

Stupperich, R. (Hrsg.), 1987, Martin Bucers Deutsche Schriften Band 6,3. Martin Bucers Katechismen aus den Jahren 1534, 1537, 1543, Gütersloher Verlagshaus Gerd Mohn, Gütersloh.

Zachman, R.C., 2006, John Calvin as teacher, pastor and theologian: The shape of his writings and thought, Baker Academic, Grand Rapids, MI.

Zillenbiller, A., 2002, 'Instruction et confession de foy dont on use en l'Eglise de Genève. Catechismus ecclesiæ Geneuensis, hoc est, formula erudiendi pueros in doctrina Christi', in A. Zillenbiller \& M. Val (eds.), Ioannis Calvini Opera Omnia III. Scripta Ecclesiastica II. Preadicatorum de Trinitate. Edidit Marc Val, vol. IX-XX111, pp. 1-121, Librairie Droz, Genève.

Zillenbiller, A., 2006, 'Genfer Bekenntnis 1536/37', in M. Bucsay \& E. Busch (Hrgs.), Reformierte Bekenntnisschriften Band I/2 1535-1549, pp. 97-136, Neukirchener Verlag, Neukirchen.

Zillenbiller, A. \& Val, M. (eds.), 2002, Ioannis Calvini Opera Omnia III. Scripta Ecclesiastica II. Preadicatorum de Trinitate. Edidit Marc Val, Librairie Droz, Genève. 